https://doi.org/10.5817/OS2021-4-9

\title{
Нов речник на новите думи в българския език
}

БЛАГОЕВА, Д. - КОЛКОВСКА, С. (ред.): Речник на новите думи в българския език (от пгрвите две десетилетия на XXI век. София: Наука и изкуство, 2021. 336 стр. ISBN 978-954-02-0351-5.

Непрекъснатото обогатяване на лексиката на българския език чрез заемане и чрез създаване на нови думи от домашни и заети компоненти създава необходимост от нейното периодично лексикографско описание. Отговор на тази необходимост дава рецензираният речник. Неговите автори (Д. Благоева, С. Колковска, В. Сумрова, Ат. Атанасова, Цв. Георгиева, Н. Костова, Св. Манова) са сътрудници от Секцията за българска лексикология и лексикография на Института за български език „Проф. Любомир Андрейчин“ при БАН. Този речник е своеобразно продължение на издадените по-рано неологични речници „Речник на новите думи и значения в българския език“ (2001 г.) и „Речник на новите думи в българския език (от края на $\mathrm{XX}$ и първото десетилетие на XXI век“ (2010г.) отново от сътрудници на Института (Ем. Пернишка, Д. Благоева, С. Колковска).

Третият по ред речник включва общо около 2000 нови думи и съставни названия, част от които фразеологизми, както и нови значения на утвърдени в езика лексикални единици. Като заглавни единици са включени и представки или първи съставни части на сложни думи, към които са приведени без тълкуване примери, съдържащи съответните компоненти.

Времевият диапазон на Речника се покрива частично с този на предходния речник (от 2010 г.), но обхваща само думи и изрази, не намерили място в него поради ниската им честотност през този период (напр. биткойн или копипейст). Засилената употреба на тези изрази през следващото десетилетие дава основания на авторите да ги включат в новия речник. ${ }^{1}$

Речникът обхваща лексикални единици от областта на обществено-политическия живот, икономиката, финансите, интернет и новите дигитални технологии, екологията, медицината, музиката, спорта, модата и др. По-голямата част от единиците назовават нови обекти и явления от съответните сфери (напр. брекзит, брекзитгр/брекзитер, дрон, дронаджия, ердоганизация, кликер, корпоратокращия, майданеи, облачнобазиран, добавена реалност), други служат

1 Вж. BLAGOEVA, D. - KOLKOVSKA, S. (red.): Rečnik na novite dumi v bălgarskija ezik (ot părvite dve desetiletija na XXI vek. Sofija: Nauka i izkustvo, 2021, c. 5 . 
за стилистично-експресивно преназоваване на явления, за които в езика вече съществуват едно- или многословни названия, напр. пазарувка разг. 'пазаруване', нискотарифка разг. 'нискотарифна авиокомпания'.

Струва си да се отбележи, че от лексикалните единици, свързани с пандемичната ситуация от началото на 2020 г. досега, в Речника са отразени някои думи с първа съставна част корона- (представена като заглавка със значение 'който се отнася до коронавирус'), напр.: коронакриза, коронащаб, коронаистерия, коронамерки и др. (изброени след заглавката без тълкуване), локдаун, но липсва лексемата ковид. Смятам, че тя също е в напреднал процес на лексикализация (срв. например: след прекаран ковид - инт.; заразени с ковид - инт.; България се отваря за ваксинирани и изкарали ковид, но високото ниво заразени отбльсква чуждите туристи. - инт.) и би могла да намери място в словника, така, както е направено с други названия, срв. напр. Биткойн/биткойн, Брекзит/брекзит; Майдан/майдан. Не са намерили място и прилагателните пандемичен, противоепидемичен, чието отсъствие от многотомния Речник на българския език дава основания да се предположи, че те също са нови.

Авторите поставят като условие за включването на дадена лексикална единица (дума или съставно название) в словника определената степен на устойчивост и тенденцията към разширяване на употребата, а оттам и вероятното утвърждаване в езиковата система на съответната единица. ${ }^{2}$ Речникът съдържа и някои нови термини от различни области, придобили актуалност и разпространение и сред по-широки обществени кръгове (напр.: генно допингиране, геоглобалистика, гигапиксел, димируем, плазмотерапия).

Преобладаващата част от новата лексика е заета от други езици (предимно от английски), но има и новообразувания, възникнали на домашна почва (напр.: биотаханджийница, антибежански, антибрюкселски, гипсокартонаджия, гифче, лекарствопотребление, льжебежанеи, майданизиране, мрежувам, протестьрство, протестғрствам). Авторите си дават сметка, че не всички думи и изрази, представени в Речника, в бъдеще ще станат пълноценна част от лексикалната система на българския език, но ги включват поради честотата на тяхната употреба в медийните и други типове дискурси през разглеждания период, и необходимостта от познаването на тяхното значение. Въпреки че Речникът е дескриптивен и няма претенции за нормативност, отношението на авторите към някои от включените в него думи и изрази е изразено с лексикографската бележка Нежел. (нежелателна дума или израз) - например в случаите, когато съответните неологизми, най-често заемки, заемат мястото на отдавна

2 Ibidem, c. 6 
утвърдени в българския език номинационни средства (напр. крафт, копипейст, копипействам, лайк, лайквам) и/или имат „несвойствени за нашия език изговорни особености“",, напр.: бизнескоучинг, бърнаут, джегингс, инфлуенсър, коуч, краудсорсинг, секстинг.

Независимо дали всички отразени в Речника лексикални единици ни харесват или не и независимо дали те ще намерят своето място сред утвърдените лексикални единици, или след време ще бъдат забравени и изтласкани от други, тези новонавлезли/новосъздадени образувания заслужават да бъдат описани и обяснени. Неологизмите са свидетелство за измененията, настъпващи в лексикалната система на езика през даден времеви отрязък и са проява на определени езикови тенденции, напр. тенденциите към интернационализация и към автохтонизация (национализация), към колоквиализация и интелектуализация, и др. Неологичните речници могат да послужат като ценен източник на различни езиковедски и културологични изследвания и имат своето място сред специализираните лексикографски справочници. Речникът на новите думи ще бъде полезен за широка аудитория и ще запознае любознателните читатели със значението на голяма част от новонавлезлите или новосъздадени лексикални единици, които поради своята новост не са интегрирани (напълно) в езиковата система и все още нямат лексикографско описание.

Цветанка Аврамова

\section{Литература:}

BLAGOEVA, D. - KOLKOVSKA, S. (red.): Rečnik na novite dumi v bălgarskija ezik (ot părvite dve desetiletija na XXI vek. Sofija: Nauka i izkustvo, 2021. $336 \mathrm{str}$. ISBN 978-954-02-0351-5.

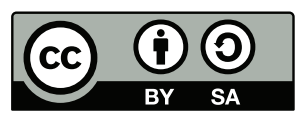

This work can be used in accordance with the Creative Commons BY-SA 4.0 International license terms and conditions (<https://creativecommons.org/licenses/by-sa/4.0/legalcode>). This does not apply to works or elements (such as images or photographs) that are used in the work under a contractual license or exception or limitation to relevant rights.

3 Ibidem. 